\title{
Roles of European and Japanese larch in the genetic control of growth, architecture and wood quality traits in interspecific hybrids (Larix $\times$ eurolepis Henry)
}

\author{
Luc E. PÂQUES* \\ INRA, Unité d'Amélioration, de Génétique et de Physiologie des Arbres forestiers, 45166 Olivet Cedex, France
}

(Received 7 November 2001; accepted 23 December 2002)

\begin{abstract}
The respective roles of European and Japanese larch species in the genetic control of traits in interspecific hybrids are examined. Two incomplete factorial mating design experiments involving European larch clones of Sudetan origin as the female parent and Japanese larch clones as the male parent have been used for that purpose. Traits investigated include growth, architecture and wood quality parameters up to 16 years old. Results indicate that traits can be grouped into three categories according to the level of control by parental species: (i) height growth controlled nearly equally by both parents, (ii) BH diameter, stem volume and architecture traits under a strong Japanese larch control and (iii) wood quality parameters predominantly controlled by the European larch. Several traits showed moderate to high full-sib family heritabilities (over 0.8): total height, stem volume, branch angle and wood density, while others like heartwood proportion, taper, density of branching or stem straightness showed low values. Several traits appear to be under non-negligible non-additive genes effects: heartwood proportion, taper, stem straightness, BH girth and modulus of elasticity. Implications for further breeding are discussed.
\end{abstract}

Larix / hybridisation / heritability / growth / stem form / wood properties

Résumé - Contribution du mélèze d'Europe et du mélèze du Japon dans le contrôle génétique de la croissance, de l'architecture et de la qualité du bois chez le mélèze hybride (Larix $\times$ eurolepis Henry). Cette étude examine l'importance relative du mélèze d'Europe et du mélèze du Japon dans le contrôle génétique des caractères chez le mélèze hybride. Deux plans de croisements factoriels incomplets sont analysés : ils impliquent des clones de mélèze d'Europe, originaires des Sudètes, comme parents femelles et des clones de mélèze du Japon comme parents mâles. Les caractères étudiés comprennent des paramètres de croissance, d'architecture et de qualité du bois entre 2 et 16 ans. Les principaux résultats indiquent que ces caractères peuvent être groupés en 3 catégories suivant le degré de contrôle de chacune des 2 espèces parentales : (i) la croissance en hauteur contrôlée à part sensiblement égale par les 2 espèces, (ii) la croissance en diamètre et en volume et les paramètres d'architecture sous déterminisme fort du mélèze du Japon, et (iii) les propriétés du bois sous contrôle du mélèze d'Europe. Plusieurs caractères présentent des héritabilités (au niveau familles de pleins-frères) fortes $(>0.8)$ : hauteur, volume, angle des branches, densité du bois par opposition à d'autres comme le pourcentage de duramen, l'élancement, la densité de branchaison ou la rectitude de la tige. Plusieurs paramètres également sont sous l'influence de gènes à caractère non-additif : pourcentage de duramen, élancement et rectitude de la tige, diamètre, module d'élasticité. Les conséquences sur le choix d'une stratégie d'amélioration sont discutées.

mélèze / hybride / heritabilité / croissance / architecture / propriétés du bois

\section{INTRODUCTION}

In addition to their roles in native mountainous ranges, larches are much appreciated for afforestation or reforestation in lowlands. Besides their fast juvenile growth, larches are valued for their high quality timber, their wind firmness, their susceptibility to only a limited number of pests and their amenity. Among larches, hybrids between European (Larix decidua Mill.) and Japanese (Larix kaempferi (Lamb.) Carr.) larch seem likely to play an increasing role in north-western European forestry.

European and Japanese larches appear complementary for several traits [29]: while Japanese larch is nearly canker resist- ant and has a faster juvenile growth, European larch is more or less sensitive to canker and is much more resistant to late frost and to summer drought than Japanese larch. As well, Japanese larch has usually a poorer stem form and a coarser branching. Differences for wood quality parameters have been reported as well.

Though geographically distant and morphologically distinct, European and Japanese larches are closely related as suggested by molecular markers in several studies [10, 24, 31, 36]. Interspecific hybrids between these two larches have been known for more than a century. The two species hybridise easily and thousands of hybrids have been produced across Europe in open-pollinated conditions and by controlled crossing.

\footnotetext{
* Corresponding author: paques@ orleans.inra.fr
} 
Superiority of hybrids over European or Japanese larch controls has been described by many authors [e.g. 5, 11, 14, $20,23,30]$ for several traits including phenology, growth, stem form and wood quality parameters. But, in contrast to these optimistic results, two major facts must be underlined regarding interspecific breeding in larch. Firstly, the basic cause of this superiority has been little documented (complementation of traits and/or heterosis) and secondly, very few commercial varieties have been issued from breeding programmes compared to the large number of combinations produced. Indeed, as observed in our own interspecific breeding programme, many hybrids fail to reach the minimum selection standards for growth, stem form and wood quality [29].

Part of this relatively limited success might be connected to the inefficiency of phenotypical selection of parent clones (e.g. hidden stem form defects at age of selection, lack of relationship between phenotypical and genetic values) as suggested by Keiding and Olsen [15]. Another reason may be the lack of knowledge of the genetic control of traits in larch interspecific hybrids. With a few known exceptions [14, 21, 25, 26], appropriate mating designs (diallel or factorial mating plans) are mostly missing and information on quantitative genetic control of traits is rare. As a result, breeders have currently no basis to efficiently select candidate parents of hybrids and hybrid vigour is still mostly unpredictable.

The objective of this study is to report results on genetic parameters obtained from two interspecific factorial mating designs. They concern growth, stem architecture and wood quality traits up to 16 years old from sowing of seed. In particular, the relative contributions of parental species to total variation is evaluated as well as the relative part of additive versus non-additive effects in the genetic control of traits. Implications for further breeding are then discussed.

\section{MATERIALS AND METHODS}

Two factorial mating designs $(12 \times 6$ and $9 \times 7)$ were created by controlled crossing in March 1982. Both of them include, as female clones, a common set of 9 clones out of 12 which were selected in the native range of the European larch: 11 non-related clones from the Sudetan Mountains and 1 clone from the Alps. As for the male clones, two independent sets of clones have been used: 6 non-related clones of Japanese larch have been used for the first mating design and 7 related clones for the second. The former were phenotypically selected for growth and stem form from various native Japanese origins in a provenance trial at 22 years old. The latter were obtained after two generations of crossings among full-sib parents. All these clones are part of the INRA breeding populations for European and Japanese larches.

Creation of mating plans by controlled crossing is usually laborious in larch because of capricious flowering and low seed set [6]. Due to several failures in crossing, only incomplete mating plans could be obtained with 30 progenies (out of 72) in the first one (Factorial 1) and 29 (out of 63) in the second one (Factorial 2). Each parent clone was involved in at least 2 successful crossings with the other species.

In May 1983, seedlots were sown at INRA nursery in Orléans, where seedlings were lined out one year later. They were then planted as bare-root seedlings at a $3 \times 3 \mathrm{~m}$ spacing in the forest in April 1985 . The experimental site is located in Beaumont-du-Lac (West of Massif Central Mountain, Haute-Vienne, Longit. $1^{\circ} 50^{\prime} \mathrm{E}$, Lat. $45^{\circ} 45^{\prime} \mathrm{N}$, alt.
$540 \mathrm{~m}$ ): plants from the 2 mating designs were inter-mixed in the same plantation. An incomplete randomised block design with 40 blocks, 42 trees per block and one-tree plot has been used. Full-sib families include on average 22.4 and 21.5 individuals respectively in mating plans 1 and 2. No fertilisation was applied and the stand was not yet thinned at time of last measurements.

From 2 to 16 years old (from sowing), data have been accumulated through periodic measurements. The main traits evaluated include:

- growth: Total height, BH girth and stem volume. Volume (up to a top diameter of $7 \mathrm{~cm}$ ) has been evaluated following [43] using both BH girth and total height when available or only BH girth.

- stem architecture: Height/BH Diameter ratio (both parameters expressed in the same unit), stem straightness, branching density and branch angle. Stem straightness was scored on a 5-point grading system with 1: heavily crooked and 5: straight stem; Branching density was estimated as the ratio of the number of branches on the 1988stem increment to the length of that increment and expressed as the number of branches per $10 \mathrm{~cm}$ long shoot; A 4-point grading system was used to estimate branch angle from the 1988 -stem increment with $1=0-25^{\circ}$ angle up to $4=75-100^{\circ}$ angle with the stem.

- wood quality: Pilodyn needle penetration, overall wood density, proportion of heartwood. A 6 J-Pilodyn device was used over bark with a 2-mm diameter-needle. Overall density was estimated from intraring density obtained by direct-scanning X-ray densitometry system on radial increment cores: only the last 6 rings have been included in this estimation. The lengths of heartwood and sapwood along two small boards cut in two opposite radial cores were measured based on eye-visible colour differentiation of the wood. The proportion of heartwood at $\mathrm{BH}$ was then expressed as the ratio of the heartwood area on total stem area (under bark). Modulus of elasticity was estimated from measurements on standing trees using a device developed by INRA and described in [16].

Data were first submitted to analysis of variance including progeny (random) and block (fixed) as main effects using OPEP statistical package [2] and were then adjusted for block effects because of software restrictions. A second analysis was then performed based on the following model:

$$
Y_{i j k}=\mu+f_{i}+m_{j}+f \times m_{i j}+\varepsilon_{i j k}
$$

with $\mu=$ general mean, $f_{i}, m_{j}=$ female and male random effects, $f \times$ $\mathrm{m}_{\mathrm{ij}}=$ female $\times$ male interaction random effect, $\varepsilon_{\mathrm{ijk}}=$ residual effect.

Degrees of freedom for blocks were considered to correct this model for block effects adjustment.

Due to imbalance in the mating designs, expected components of variance have been estimated with the $\mathrm{S}+$-varcomp procedure using the REML option [1]. The contribution of female $\left(V_{f}\right)$ and male $\left(V_{m}\right)$ variance components (equal to general hybridisation ability variance) and of the interaction variance $\left(\mathrm{V}_{\mathrm{fxm}}\right.$, equal to specific hybridisation ability variance) have been computed and related to the total variance. Since parental clones belong to two different species, only biased estimates of additive variance components could be estimated and subsequently narrow-sense heritabilities would also be biased. Therefore, only family heritabilities have been presented, separately for female and male half-sib families as well as for hybrid full-sib families. To express ratio of additive to non-additive effects, ratios of specific hybridisation ability (SHA) variance over general hybridisation ability (GHA) variance have been computed as

$$
\text { SHA/GHA }=V_{\mathrm{fxm}} /\left(\mathrm{V}_{\mathrm{f}}+\mathrm{V}_{\mathrm{m}}\right) / 2 .
$$

Standard errors of genetic parameters have been estimated by the Jacknife method [3]. 
Table I. Means and phenotypic coefficients of variation (CVp) and extreme family performances (Min.-Max.).

\begin{tabular}{|c|c|c|c|c|c|c|c|}
\hline & \multirow{2}{*}{ Age } & \multicolumn{3}{|c|}{ Factorial 1} & \multicolumn{3}{|c|}{ Factorial 2} \\
\hline & & Mean & $\operatorname{CVp}(\%)$ & Min.-Max. & Mean & $\operatorname{CVp}(\%)$ & Min.-Max. \\
\hline & & \multicolumn{6}{|c|}{ Growth traits } \\
\hline Total height $(\mathrm{cm})$ & 11 & 919 & 20 & $761-1020$ & 905 & 18 & $761-1107$ \\
\hline $\mathrm{BH}$ girth $(\mathrm{mm})$ & 15 & 567 & 20 & $409-643$ & 558 & 18 & $409-634$ \\
\hline \multirow[t]{2}{*}{ Stem volume $\left(\mathrm{dm}^{3}\right)$} & 15 & 252 & 41 & $128-330$ & 238 & 39 & $128-325$ \\
\hline & & \multicolumn{6}{|c|}{ Stem architecture } \\
\hline Branch angle & 6 & 2.0 & 34 & $1.3-2.7$ & 2.3 & 28 & $1.8-2.9$ \\
\hline $\begin{array}{l}\text { Density of branching } \\
\text { (no of branches } / 10 \mathrm{~cm} \text { ) }\end{array}$ & 6 & 3.1 & 54 & $2.0-4.2$ & 3.0 & 36 & $2.4-3.8$ \\
\hline $\mathrm{H} / \mathrm{D}$ & 11 & 72.0 & 16 & $64.9-86.7$ & 71.8 & 13 & $62.7-86.7$ \\
\hline \multirow[t]{2}{*}{ Stem straightness } & 15 & 4.0 & 26 & $2.7-4.5$ & 4.0 & 25 & $3.1-4.8$ \\
\hline & & \multicolumn{6}{|c|}{ Wood quality parameters } \\
\hline Pilodyn (mm) & 11 & 14.6 & 19 & $11.6-17.6$ & 14.8 & 18 & $13.1-17.2$ \\
\hline $\begin{array}{l}\text { Heartwood proportion } \\
\text { (\% of stem area) }\end{array}$ & 13 & 37.0 & 30 & $28.8-49.7$ & 37.0 & 29 & $28.3-49.7$ \\
\hline Density $\left(\mathrm{kg} / \mathrm{m}^{3}\right)$ & 13 & 411.2 & 10 & $375.9-447.8$ & 408.0 & 9 & $364.2-444.9$ \\
\hline $\operatorname{MOE}(\mathrm{MPa})$ & 16 & 7303 & 23 & 5598-9149 & - & - & - \\
\hline
\end{tabular}

\section{RESULTS}

\subsection{Mean performances}

Population means, coefficients of variation and family ranges are given in Table I. Survival rate (not tabulated) was over $90 \%$ for both factorials. Growth rates are judged satisfactory in this type of site, nutritionally poor and with a low water retention. Indeed, the average annual height increment reaches nearly 1 metre from plantation time and the average ring width, nearly $7 \mathrm{~mm}$. Average stem straightness (around score 4) is slightly better than commonly recorded in most of our trials. Wood quality parameters are in the range of values known so far for hybrid larch of that age grown at low elevations [9, 19, 23].

Performances are similar in both factorials but with a slightly but consistently lower phenotypic variability for factorial 2, not unexpected from its male parents' pedigree. In both factorials, the range of mean family performances is wide for most traits (especially volume), except for wood density.

\subsection{Genetic components of variation}

\subsubsection{Growth traits}

For total height, differences among European larch female clones are increasing over years and significant to highly significant differences are observed at any age except at 2 and 4 years from sowing for factorial 1 (Tab. II). The same trend is shown for the Japanese larch males even among the related ones from factorial 2.

Male, female and interaction variance components are presented in Table II and in Figure 1, as percentage of total vari- ation. As it can be seen from factorial 1, their overall contribution to total variation for total height is increasing over years and reaches up to $50 \%$ at 16 years old. However, trends are different according to components. While both male and female components are increasing over years, the female $\times$ male interaction term is drastically decreasing: highly significant and close to $20 \%$ at 2 yrs old, it drops down to less than $2 \%$ at 6 yrs old and it is not any more significant. It levels off around this value till at least 11 years old. A significant interaction is found back at 16 years old but the component represents less than $7 \%$ of total variation.

The female component is exclusive at the nursery stage: the male contribution is zero at this stage. But later on, the contributions of both main factors are getting closer but with still a slight advantage for the female parent (see $\mathrm{Vm} / \mathrm{Vf}$, Tab. II).

For factorial 2, the same trend is globally observed but the female factor remains pre-dominant much longer; the male contribution is getting close to the female one only at 11 years old $(\mathrm{Vm} / \mathrm{Vf}=0.85)$. The male $\times$ female interaction component is also significant at the earliest ages till 5 years old but it nearly disappears thereafter.

For diameter and volume between 11 and 16 years old, highly significant differences are also found among both male and female clones as for total height (Tab. III). Male $\times$ female interactions are mostly significant for factorial 1 over that period but not for factorial 2. At the oldest age, they are not any more or weakly significant for stem volume and girth. Their contribution to total variation does not exceed $3 \%$ and $6 \%$ respectively for volume and girth (Fig. 2). Male and female factors remain the main components of total variation. In contrast to total height, the Japanese larch male component is usually higher than that of the European larch female: $\mathrm{Vm} / \mathrm{Vf}$ ratio is equal to 1.3 at 16 years old. 
Table II. Total height: variance component estimates and their level of significance (F-test).

\begin{tabular}{|c|c|c|c|c|c|c|c|c|c|c|}
\hline \multirow{2}{*}{ Age } & \multicolumn{5}{|c|}{ Factorial 1} & \multicolumn{5}{|c|}{ Factorial 2} \\
\hline & EL female & JL male & $\mathrm{f} \times \mathrm{m}$ & Resid. & $\mathrm{Vm} / \mathrm{Vf}$ & EL female & JL male & $\mathrm{f} \times \mathrm{m}$ & Resid. & $\mathrm{Vm} / \mathrm{Vf}$ \\
\hline 2 & $2.3 \mathrm{~ns}$ & $0.0 \mathrm{~ns}$ & $58.1 * * *$ & 221.7 & 0.0 & - & - & - & - & - \\
\hline 4 & $59.9 \mathrm{~ns}$ & $83.0 *$ & $87.0 * * *$ & 623.1 & 1.4 & $73.5^{*}$ & $0.8 \mathrm{~ns}$ & $29.5 * *$ & 541.0 & 0.0 \\
\hline 5 & $174.6^{*}$ & $196.8^{* *}$ & $88.2 * *$ & 1323.2 & 1.1 & $139.7 * *$ & $25.2 \mathrm{~ns}$ & $45.0^{*}$ & 1276.9 & 0.2 \\
\hline 6 & $545.7 * * *$ & $451.6 * * *$ & $66.0 \mathrm{~ns}$ & 2573.4 & 0.8 & $337.2 * *$ & $116.7 \mathrm{~ns}$ & $60.4 \mathrm{~ns}$ & 2585.7 & 0.4 \\
\hline 8 & $1069.7 * * *$ & $721.3 * * *$ & $42.3 \mathrm{~ns}$ & 3958.0 & 0.7 & $818.7 * * *$ & $383.1 * * *$ & $0.0 \mathrm{~ns}$ & 3568.8 & 0.5 \\
\hline 9 & $1237.7 * * *$ & $1063.1 * * *$ & $129.0 \mathrm{~ns}$ & 4643.7 & 0.9 & $1041.2 * * *$ & $569.3 * * *$ & $0.0 \mathrm{~ns}$ & 4358.1 & 0.6 \\
\hline 10 & $1519.4 * * *$ & $1278.3^{* * *}$ & $143.5 \mathrm{~ns}$ & 5529.8 & 0.8 & $1231.2 * * *$ & $897.1 * * *$ & $0.0 \mathrm{~ns}$ & 5417.7 & 0.7 \\
\hline 11 & $1806.0 * * *$ & $1644.2 * * *$ & $228.6 n s$ & 6575.0 & 0.9 & $1467.3 * * *$ & $1244.2 * * *$ & $0.0 \mathrm{~ns}$ & 6480.8 & 0.9 \\
\hline 16 & $3620.9 * *$ & $2989.6 * *$ & $1043.6^{* *}$ & 7859.3 & 0.8 & - & - & - & - & - \\
\hline
\end{tabular}

$*, * *, * * *$ Significant at $\alpha=5,1$ and $0.1 \%$ respectively.

Table III. BH.girth and stem volume: variance component estimates and their level of significance (F-test).

\begin{tabular}{|c|c|c|c|c|c|c|c|c|c|c|}
\hline \multirow{2}{*}{ Age } & \multicolumn{5}{|c|}{ Factorial 1} & \multicolumn{5}{|c|}{ Factorial 2} \\
\hline & EL female & JL male & $\mathrm{f} \times \mathrm{m}$ & Resid. & $\mathrm{Vm} / \mathrm{Vf}$ & EL female & JL male & $\mathrm{f} \times \mathrm{m}$ & Resid. & $\mathrm{Vm} / \mathrm{Vf}$ \\
\hline \multicolumn{11}{|c|}{ BH.girth } \\
\hline 11 & $777.0 * *$ & $903.8 * * *$ & $215.8 * *$ & 3573.4 & 1.2 & $568.0 * * *$ & $447.3 * *$ & $60.8 \mathrm{~ns}$ & 3550.9 & 0.8 \\
\hline 13 & $822.7 *$ & $1072.2 * *$ & $540.5 * * *$ & 4253.2 & 1.3 & $526.2 * *$ & $761.8 * * *$ & $123.7 \mathrm{~ns}$ & 4887.0 & 1.5 \\
\hline 15 & $495.3 \mathrm{~ns}$ & $1677.7 * *$ & $1070.2 * * *$ & 7017.1 & 3.1 & $515.4 *$ & $1613.7 * * *$ & $301.2 *$ & 7593.5 & 3.4 \\
\hline $16^{(1)}$ & $53.2 *$ & $67.6 *$ & $29.0 *$ & 337.4 & 1.3 & - & - & - & - & - \\
\hline \multicolumn{11}{|c|}{ Stem volume } \\
\hline 11 & $125.7 * * *$ & $138.4 * * *$ & $10.752 \mathrm{~ns}$ & 472.3 & 1.1 & $93.8 * * *$ & $78.7 * * *$ & $1.0 \mathrm{~ns}$ & 410.0 & 0.8 \\
\hline 13 & $654.6 * *$ & $875.6^{* * *}$ & $237.4 * *$ & 3106.4 & 1.3 & $421.3 * * *$ & $608.6^{* * *}$ & $44.3 \mathrm{~ns}$ & 3063.6 & 1.4 \\
\hline 15 & $651.5 \mathrm{~ns}$ & $1773.0 * * *$ & $674.2 * * *$ & 6347.3 & 2.7 & $612.9 * * *$ & $1677.0 * * *$ & $139.5 \mathrm{~ns}$ & 6363.5 & 2.7 \\
\hline 16 & $389.1 * *$ & $493.2 * * *$ & 76.9ns & 1734.1 & 1.3 & - & - & - & - & - \\
\hline
\end{tabular}

(1) Diameter instead of girth.
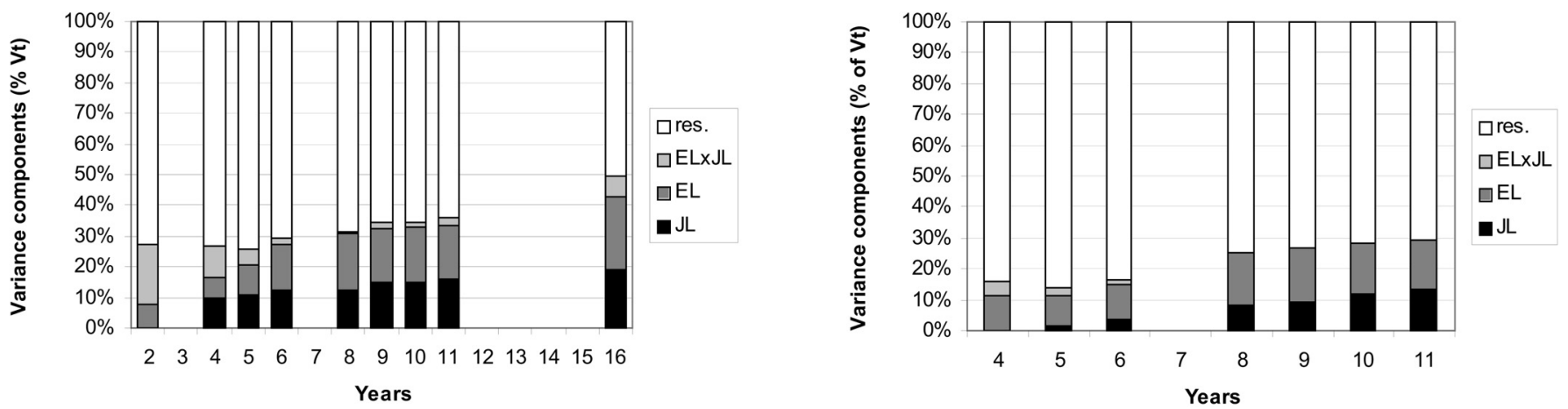

Figure 1. Total height: variance components for males (JL), females (EL), females $\times$ males $(\mathrm{EL} \times \mathrm{JL})$ and residual (res.) over years expressed in \% of total variance. (Factorials 1 (left) and 2 (right).)

\subsubsection{Stem architecture}

In factorial 1, only Japanese larch male parents differ significantly among themselves for stem straightness (Tab. IV). In factorial 2, differences among parents of both species are observed but they are also much stronger among the male related clones than among female clones. In both factorials, the Japanese larch male component of variance is much higher than that of European larch (Fig. 2) and the ratio $\mathrm{Vm} / \mathrm{Vf}$ is increasing over years in favour of the Japanese larch parent. 

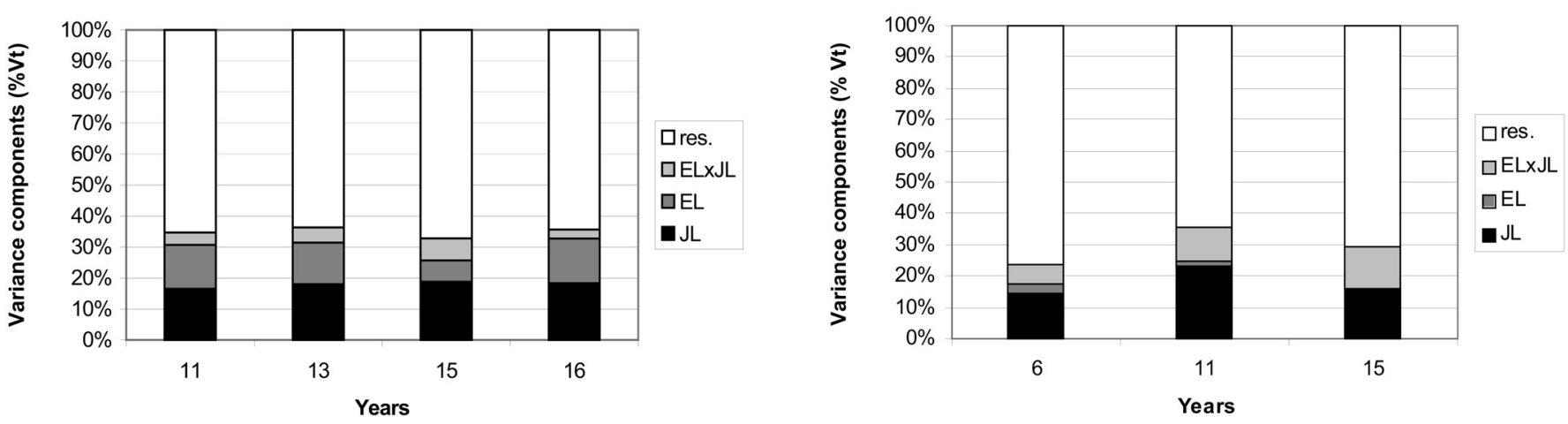

Figure 2. Variance components (as specified in caption of Fig. 1) over years expressed in \% of total variance. (Factorial 1: stem volume (left) and stem straightness (right).)

Table IV. Stem architecture: variance component estimates and their level of significance (F-test).

\begin{tabular}{|c|c|c|c|c|c|c|c|c|c|c|c|}
\hline & \multirow{2}{*}{ Age } & \multicolumn{5}{|c|}{ Factorial 1} & \multicolumn{5}{|c|}{ Factorial 2} \\
\hline & & EL female & JL male & $\mathrm{f} \times \mathrm{m}$ & Resid. & $\mathrm{Vm} / \mathrm{Vf}$ & EL female & JL male & $\mathrm{f} \times \mathrm{m}$ & Resid. & $\mathrm{Vm} / \mathrm{Vf}$ \\
\hline \multicolumn{12}{|c|}{ Stem straightness } \\
\hline \multirow{3}{*}{$\begin{array}{l}\text { Stem } \\
\text { straightness }\end{array}$} & 6 & $0.038 \mathrm{~ns}$ & $0.182 * *$ & $0.076^{*}$ & 0.954 & 4.8 & $0.108 * * *$ & $0.046 * *$ & $0.000 \mathrm{~ns}$ & 0.983 & 0.4 \\
\hline & 11 & $0.015 \mathrm{~ns}$ & $0.272 * *$ & $0.131 * * *$ & 0.752 & 18.1 & $0.072 * *$ & $0.135 * * *$ & $0.004 \mathrm{~ns}$ & 0.750 & 1.9 \\
\hline & 15 & $0.000 \mathrm{~ns}$ & $0.186^{*}$ & $0.152 * * *$ & 0.821 & $>$ & $0.027 *$ & $0.105 * * *$ & $0.000 \mathrm{~ns}$ & 0.914 & 3.9 \\
\hline \multicolumn{12}{|c|}{ Total height/BH. Diameter ratio } \\
\hline \multirow[t]{2}{*}{$\mathrm{H} / \mathrm{D}$} & 11 & $3.101 \mathrm{~ns}$ & $6.190^{*}$ & $5.019 * * *$ & 55.4 & 2.0 & $5.514 *$ & $0.900 \mathrm{~ns}$ & $1.946^{*}$ & 63.274 & 0.2 \\
\hline & 16 & $1.490 \mathrm{~ns}$ & $0.000 \mathrm{~ns}$ & $4.078^{*}$ & 44.3 & 0 & - & - & - & - & - \\
\hline \multicolumn{12}{|c|}{ Branching } \\
\hline Angle & 6 & $0.022 \mathrm{~ns}$ & $0.095 * * *$ & $0.016^{*}$ & 0.297 & 4.4 & $0.037 * * *$ & $0.058 * * *$ & $0.000 \mathrm{~ns}$ & 0.319 & 1.6 \\
\hline Density & 6 & $0.069^{*}$ & $0.159 * * *$ & $0.000 \mathrm{~ns}$ & 1.658 & 2.3 & $0.065 * * *$ & $0.012 \mathrm{~ns}$ & $0.000 \mathrm{~ns}$ & 1.252 & 0.2 \\
\hline
\end{tabular}

A major difference between the 2 factorials concerns the importance of interaction effects. They are highly significant in the first one but not in the second; for the first factorial, they are a major component of total variation with about the same proportion of total variation as the male parent (13.2 compared to 16.0). Male $\times$ female interaction component doubles from 6 to 15 years old: 6.1 and $13.2 \%$ respectively (Fig. 2).

Total height/BH diameter ratio, which is a measure of slenderness but also of wind stability, shows at 11 years old about the same pattern as stem straightness. The Japanese larch contribution is higher than that of European larch in factorial 1 but neither at 15 years old nor in factorial 2 ; and the male $\times$ female interaction term is significant in both factorials. The latter represents a major genetic component of total variation: $7.2 \%$ compared to 4.5 and $8.9 \%$ respectively for female and male components in factorial 1 and $2.7 \%$ compared to 1.3 and $7.7 \%$ respectively for female and male components in factorial 2.

For branching, both Japanese and European larch clones show highly significant differences except among females for branch angle in factorial 1 and among males in factorial 2 for branch density (Tab. IV). For both traits in factorial 1 and for branch angle only in factorial 2, the male Japanese component is higher than that of European larch; for branch angle, it reaches $14.0 \%$ of total variance compared to $8.9 \%$ in factorial 1 and $22.2 \%$ compared to $5.0 \%$ in factorial 2 ; for branch density in factorial 1, it represents $8.4 \%$ versus $3.7 \%$ for the European clones. Interaction is mostly not significant or only weakly.

\subsubsection{Wood quality parameters}

For heartwood proportion, neither European larch clones nor Japanese larch parents differ significantly (Tab. V). The ratio $\mathrm{Vm} / \mathrm{Vf}$ is in both factorials equal to 0 . The interaction term is in both cases a major variance component exceeding both parents effects: $22.4 \%$ and $5.8 \%$ respectively in factorials 1 and 2 compared to $9.6 \%$ and $4.1 \%$ respectively for European larch.

For wood density (pilodyn and overall density), highly significant differences can be found among clones in both parental species but interaction effects are not significant. Results are highly consistent from factorial to factorial. As for heartwood proportion, the European larch female component is much higher than that of Japanese larch (Fig. 3): for example for density, it reaches $25.1 \%$ compared to $4.2 \%$ for Japanese larch in the first factorial and $29.0 \%$ and $10.0 \%$ respectively in the second factorial. The female $\times$ male interaction component represents less than $1 \%$ of total variation. 
Table V. Wood quality parameters: variance component estimates and their level of significance (F-test).

\begin{tabular}{|c|c|c|c|c|c|c|c|c|c|c|c|}
\hline & \multirow{2}{*}{ Age } & \multicolumn{5}{|c|}{ Factorial 1} & \multicolumn{5}{|c|}{ Factorial 2} \\
\hline & & EL female & JL male & $\mathrm{f} \times \mathrm{m}$ & Resid. & $\mathrm{Vm} / \mathrm{Vf}$ & EL female & JL male & $\mathrm{f} \times \mathrm{m}$ & Resid. & $\mathrm{Vm} / \mathrm{Vf}$ \\
\hline Heartwood & 13 & $0.002 \mathrm{~ns}$ & $0.000 \mathrm{~ns}$ & $0.004 \mathrm{~ns}$ & 0.012 & 0.0 & $0.005 \mathrm{~ns}$ & $0.000 \mathrm{~ns}$ & $0.006 * *$ & 0.100 & 0.0 \\
\hline Pilodyn & 11 & $1.119 * * *$ & $0.133 \mathrm{~ns}$ & $0.080 \mathrm{~ns}$ & 5.489 & 0.1 & $0.867 * * *$ & $0.413 * * *$ & $0.000 \mathrm{~ns}$ & 5.046 & 0.5 \\
\hline Density & 13 & $374.4 * * *$ & $63.2 * *$ & $0.000 \mathrm{~ns}$ & 1053.5 & 0.2 & $362.3 * * *$ & $124.8 * * *$ & $8.199 \mathrm{~ns}$ & 754.6 & 0.3 \\
\hline MOE & 16 & $2378.6(*)$ & $1546.5 \mathrm{~ns}$ & $1921.0 * *$ & 14629.0 & 0.7 & - & - & - & - & \\
\hline
\end{tabular}

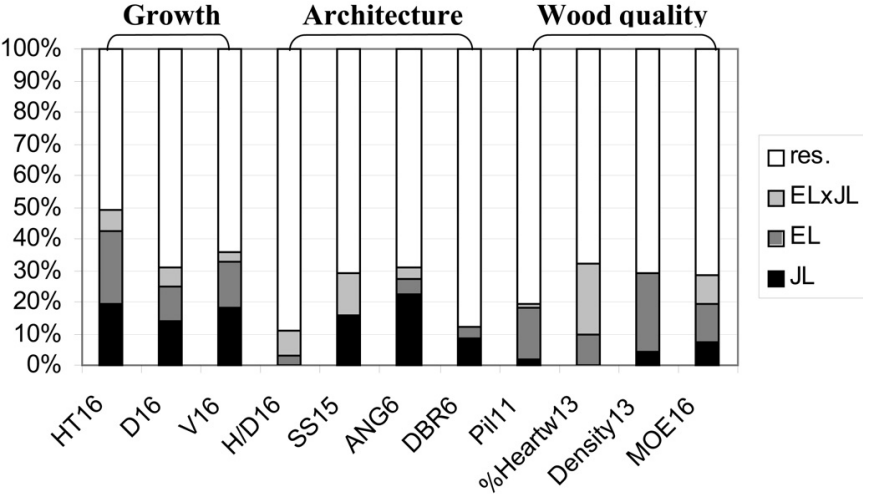

Figure 3. Variance component estimates (as specified in caption of Fig. 1) expressed in percent of total variation (Factorial 1).
Finally for stiffness (MOE), the greatest differences are found among European larch female clones and once again, the European larch variance component is higher than that of Japanese larch: $11.6 \%$ versus $7.6 \%$. Female $\times$ male interaction is significant and its variance component $(9.4 \%)$ exceeds that of Japanese larch.

\subsection{Family heritabilities and SHA/GHA ratios}

Full-sib and half-sib family heritabilities and ratios of specific over general hybridisation ability variances (SHA/GHA) are given in Table VI for the main variables at the oldest ages available. With one exception, standard errors are all lower than their parameter estimates and for the majority of them, they are small.

Looking at full-sib family -applicable if selection occurs in the hybrid population- it can be seen that traits like total height,

Table VI. Half-sib family heritabilities for female $\left(\mathrm{h}^{2} \mathrm{HSf}\right)$ and male $\left(\mathrm{h}^{2} \mathrm{HSm}\right)$ parents, full-sib family heritabilities $\left(\mathrm{h}^{2} \mathrm{FS}\right)$ and ratios of specific hybridisation ability variance over general hybridisation ability variance (SHA/GHA) (Standard error between brackets).

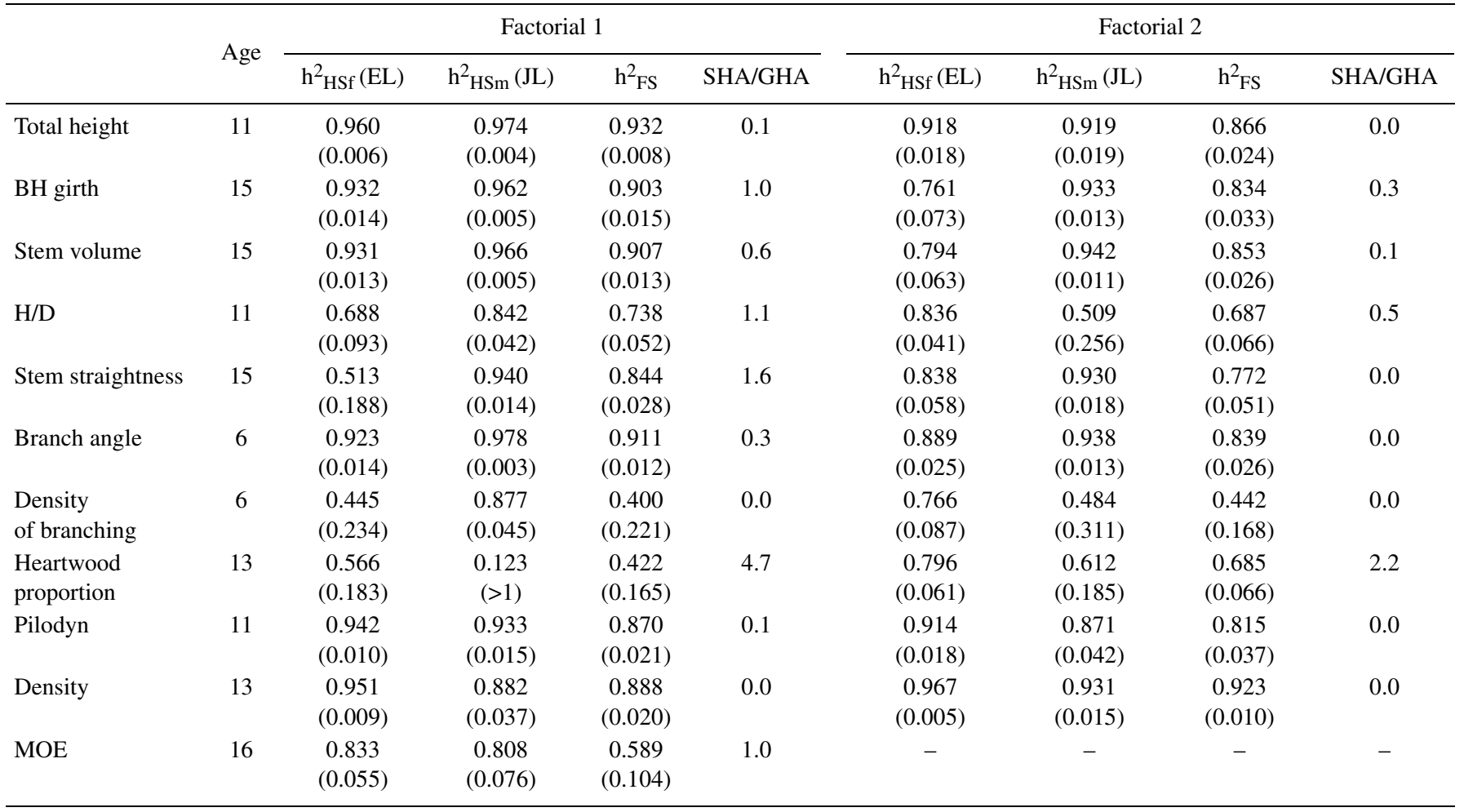


stem volume, wood density and branch angle are characterised by the highest values (>0.84). At the opposite, heartwood proportion, H/D ratio and density of branching are much less heritable (0.40-0.74). Highest genetic gains from selection might be expected from those traits with high heritability and variability such as branch angle or stem volume.

But, as expected from results above, levels of half-sib heritability are quite different among the parental species. Similar between European and Japanese larch for total height, they appear slightly to much higher in Japanese larch compared to European larch for girth, volume and stem architecture traits including branching. The only exceptions in this respect are for H/D and branch density in factorial 2. For wood quality parameters, heritabilities are all higher for the European larch parent compared to the Japanese parent.

As shown by SHA/GHA ratios, non-additive effects are particularly high in factorial 1 for heartwood proportion but also high for stem straightness, H/D, BH girth and MOE as they largely exceed or at least reach levels of additive effects. In factorial 2, the highest values are found for heartwood proportion, H/D and BH girth; but non-additive effects exceed additive effects only for heartwood proportion.

\section{DISCUSSION}

Results presented above are from a unique site, with trees still at a juvenile stage (at around 16 years of age, that is at about one third of the expected rotation). They are based on small and unbalanced sets of parent clones which most probably do not cover the whole range of species intraspecific variability. As a consequence, low accuracy on the genetic parameter estimates is expected -but in fact as already shown in Table VI, heritabilities have been estimated with a good precision- and results might apply only to a part of the breeding populations. Another problem could be connected to the imbalance in the number of European and Japanese larch parents used in crossing. But in fact, their total number across the 2 factorials is close and half-sib family heritabilities proved to be very similar.

These results are among the very few available so far for larch interspecific hybrids and they already give some important indications about the possible genetic control of the main economical traits.

Two major aspects have been considered in this study: the first one relates to the relative genetic control of traits in hybrids by female (European larch) versus male (Japanese larch) parents and the second, to the relative importance of additive versus non-additive variance components.

As shown above, traits can be grouped into three categories according to the relative importance of the female and male variance components. The first group includes traits with a quite equivalent contribution of the female and the male components, namely total height; the second group concerns traits under strong male control, i.e. BH girth and stem volume and stem architecture characters such as stem straightness (especially in Factorial 1) and branching. Finally, the third group refers to traits under strong female control, namely wood quality parameters.
For growth traits, data have clearly shown a change in the respective control of both parents over years. As in our study, Matthews et al. [21] observed the little part of the Japanese larch male variance components for both total height and diameter at nursery stage (2 years of age). Instead of a species effect, these results rather suggest maternal effects, such as the influence of seed weight on growth of seedling during the first years. But later on, the male contribution is rapidly increasing to become similar (height) or even much greater (diameter, volume) than the female one.

As shown in Table VI and summarised in Figure 3, nonadditive genetic variance (interaction effects) exists for nearly all traits except for wood density and branching density. Although significant for growth traits at 16 years old and branch angle, they only represent a small part of the total genetic variance (less than $30 \%$ ). But for stem shape (H/D and straightness) and for some wood quality properties (heartwood proportion and MOE), non-additive variance can be a major component of total genetic variance. These traits are thus characterised by the lowest full-sib family heritabilities.

Clearly, an evaluation made at a too early an age might be misleading for some characters like growth traits or stem straightness. Obviously, there is a shift in the way these traits are genetically controlled. As seen before for total height for example, non-additive (interaction) effects dominate at the early stages (up to $84 \%$ of total genetic variance at 2 years old) and rapidly (up to 4-5 years) regress in favour of additive effects. These rise up to $76 \%$ of total genetic variance at 16 years old. A similar trend of reduction of the interaction variance component over time has already been reported by several authors for conifers such as pines [e.g. 4, 8] but also larch $[13,26]$. In the latter study, it can be observed that for total height, its proportion to total variance drops from nearly $14 \%$ at 5 years old down to $8 \%$ at 7 years old. Inversely, Samuel [32] observed for Sitka spruce an inverse trend: $V_{D} / V_{A}$ ratio increased from 0.4 up to 8.3 for total height from 1 to 13 years of age and from 0.3 to 0.8 for diameter from 8 to 15 years.

Apparently a reverse shift between additive and non-additive effects can also be observed for stem straightness. This is clear in factorial 1 where female $\times$ male interaction effects are present: the ratio of SHA to GHA variance increased from 6 to 15 years old from 0.7 up to 1.6 and represented up to $62 \%$ of total genetic variance at the latest age. Samuel [32] has also found such strong non-additive effects for stem straightness at a similar age with Sitka spruce.

Comparison of heritability values and SHA/GHA ratios obtained in this study with published values for larch is difficult. Indeed results are scarce and they do not always refer to the same populations. Sindelar [39] summarised most of the information available for European larch. Together with some additional studies [38, 40], it was shown that narrow-sense heritabilities ranged from 0.16 to 0.56 for total height (between 2 and 23 years), from 0.04 up to 0.65 for BH diameter at the same ages, and 0.17 to 0.52 for stem form. Based on data from this study, biased estimates of narrow-sense heritabilities could be computed as $4 \mathrm{~V}_{\mathrm{f}} / \mathrm{Vp}$. They mostly fit into these ranges but for total height, they rather stand in the upper range while for stem form, they stand in the lower range of 
these values. Similar values are not available for Japanese larch grown in European conditions.

Several selection methods are available for interspecific breeding [22], namely reciprocal recurrent selection, recurrent selection in each of the parental populations prior to hybridisation or later in the hybrid population. But whatever the method chosen, it is of primary importance to identify which traits should be given priority for selection in each parental species.

If reciprocal effects (sense of crossing of the 2 parental species) can be considered as negligible, then the female and male contributions reported in this study could be assimilated to the contributions of the parental species themselves. Unpublished data from a $18 \times 18$ diallel mating design with reciprocal hybrids, managed by INRA, confirm this hypothesis, namely the absence of reciprocal effects. With this hypothesis, our results suggest that hybrid performances are: (i) equally controlled by both species for height growth; (ii) mostly controlled by Japanese larch for BH girth and volume growth as well as for stem architecture; and (iii) mostly controlled by European larch for wood quality traits. For all these traits, levels of heritabilities are high enough in the species predominantly controlling the trait (Tab. VI) and they can ensure an efficient selection in the respective species breeding populations if large variability exists also for the traits.

Such differential contributions to traits by parental species are well-known by breeders and are exploited in interspecific hybrids. For example for stem growth in hybrid poplar, Populus trichocarpa contributes more to height than Populus deltoïdes and the reverse is true for diameter [41]. The same is probably true for larch. While European larch competes well for height growth with Japanese larch, Japanese larch has often an advantage for diameter growth and thus for stem volume production at least during the first decades of life. For stem straightness and branching, Japanese larch is often of lower quality, as previously mentioned in the introduction. For wood density and stiffness, European larch usually offers higher values [17].

Generalising our results to any Japanese and European larch populations is probably premature. This would be particularly risky for European larch which unlike Japanese larch $[28,35]$, offers a broad variability among populations for many traits [27, 34]. Our results refer specifically to Sudetan Mountain origins of European larch. Results might be different when dealing with other quite genetically distant races or populations of European larch such as alpine or polish larch. For example, for control of stem straightness, there are some clues from our own experiment network or from results such as those by Schneck and Langner [33], that interspecific hybrids between alpine European larch and Japanese larch are mostly straighter than those described in this paper implying European larches of Sudetan origins. Alpine larch is characterised by a generally good to excellent stem straightness, and it seems to play a determinant role in the genetic control of stem straightness in interspecific hybrids compared to that of Japanese larch as in this study.

Among selection methods, reciprocal recurrent selection is probably one of the most attractive when dealing with 2 populations and a fortiori when dealing with 2 species as in our study. One of its main interests is certainly to take advantage of all genetic effects [12]. For traits identified in this study with large non-additive effects such as heartwood proportion or stem straightness, this might be appropriate. But, among the traits to be simultaneously considered in larch breeding, most seem to be under additive control: strong for many (e.g. wood density, growth) or large enough for others (e.g. stem straightness) to ensure the efficiency of selection techniques enhancing additivity. In addition, other practical and economical considerations (such as the simplicity of the strategy, the length of the breeding cycle, the relative cost of intra-species versus inter-species crossing, the urgency to release outstanding hybrid varieties, etc) might rather favour the recurrent selection approach. This is also clearly suggested by $\mathrm{Li}$ and Wyckoff [18] for hybrid larch.

Additional information and experimental results are still needed in the demonstration and the understanding of hybrid vigour in larch. Besides heterosis, hybrid superiority may also be due to additive gene actions on a combination of traits [22, 37]. Complementation of traits has already been recognised for larch canker resistance [42] and suspected for other traits $[18,25]$. Another important question to be solved is how well general combining ability (that is at the intraspecific level) relates to general hybridising ability (namely at the interspecific level), and whether it could be used to predict hybrid performance. These are key questions for interspecific breeding [7]. Appropriate mating designs combining both intra- and inter-specific hybrids have been purposely prepared in larch [29] to bring new insight to these questions.

Acknowledgments: This study has been partly supported by a grant from the European Union (FAIR-CT98-3354). We thank M. Faucher, P. Legroux and F. Millier for their technical assistance in the repeated measurements of these trials and two anonymous reviewers for their helpful comments.

\section{REFERENCES}

[1] Anonymous, S-Plus, Guide to statistical and mathematical analysis, StatSci Division, MathSoft, Inc. Seattle, Wa, 1995.

[2] Baradat P., Labbé T., OPEP, Un logiciel intégré pour l'amélioration des plantes pérennes, Séminaires de biométrie et génétique quantitative, Montpellier, 1994.

[3] Baradat P., Labbé T., Bouvet J.M., Conception d'index pour la sélection réciproque récurrente, Aspects génétiques, statistiques et informatiques, in: Traitements statistiques des essais de sélection, CIRAD (Ed.), 1995, pp. 101-150.

[4] Balocchi C.E., Bridgwater F.E., Zobel B.J., Johromi S., Age trends in genetic parameters for tree height in a nonselected population of loblolly pine, For. Sci. 39 (1993) 231-251.

[5] Baltunis B.S., Greenwood M.S., Eysteinsson T., Hybrid vigor in Larix: growth of intra-and interspecific hybrids of Larix decidua, L. laricina, and L. kaempferi after 5 years, Silvae Genet. 47 (1998) 288-293.

[6] Bonnet-Masimbert M., Baldet P., Pâques L.E., Philippe G., From flowering to artificial pollination in larch for breeding and seed orchard production, For. Chron. 74 (1998) 195-202.

[7] Dieters M.J., Dungey H.S., Relationship between the relative importance of non-additive variance and the genetic correlation 
between hybrid and parental populations in some Pinus species, in: Dungey H.S., Dieters M.J., Nikles D.G. (Compilers), Hybrid Breeding and Genetics of Forest Trees, Proc. of QFRI/CRC-SPF Symposium, 9-14 April 2000, Noosa, Queensland, Australia, pp. 87-92.

[8] Dieters M.J., White T.L., Hodge G.R., Genetic parameter estimates for volume from full-sib tests of slash pine (Pinus elliottii), Can. J. For. Res. 25 (1995) 1397-1408.

[9] Dinelli B., Propriétés mécaniques du bois de familles de mélèze hybride, École Supérieure de l'énergie et des matériaux, Orléans, Rapport de stage, 1992, 42 p.

[10] Ennos R.A., Qian T., Monitoring the output of a hybrid larch seed orchard using isozyme markers, Forestry 67 (1994) 63-73.

[11] Ferrand J.C., Bastien J.C., Bilan à 26 ans d'une plantation comparative de mélèzes, Rev. For. Fr. 27 (1985) 441-448.

[12] Gallais A., Théorie de la sélection en amélioration des plantes, Masson, Paris, 1990.

[13] Haasemann W., Ergebnisse der Leistungsprüfung 7 jähriger Lärchen-Nachkommenschften aus gelenkten Kreuzungen. Beitr. Forstwirtsch. 3 (1972) 25-29.

[14] Hering S., Braun H., Some results of larch hybrid breeding at Graupa, in Proc. 'Results and future trends in larch breeding on the basis of provenance research' IUFRO Working Party S2.02-07, Berlin, 1992, pp. 146-159.

[15] Keiding H., Olsen H.C., Assessment of stem form in clones and progenies of larch, Silvae Genet. 14 (1965) 115-122.

[16] Launay J., Rozenberg P., Pâques L.E., Dewitte J.M., A new experimental device for rapid measurement of the trunk equivalent modulus of elasticity on standing trees, Ann. For. Sci. 57 (2000) 351-359.

[17] Lavers G.M., The strength properties of timber, Princes Risborough Laboratory, Her Majesty's Stationery Office, London, 1983.

[18] Li B.L., Wyckoff G.W., Breeding strategies for Larix decidua, L. leptolepis and their hybrids in the United States, For. Genet. 1 (1994) 65-72.

[19] Maréchal M., Jacques D., Evaluation de deux méthodes acoustiques de détermination du module d'élasticité de bois de mélèze hybride jeune (Larix $\times$ eurolepis Henry) - comparaison avec une méthode normalisée en flexion statique, Ann. For. Sci. 56 (1999) 333-343.

[20] Matyssek R., Schulze E.D., Heterosis in hybrid larch (Larix decidua $\times$ leptolepis). II. Growth characteristics, Trees 1 (1987) $225-231$.

[21] Matthews J.D., Mitchell A.F., Howell R., The analysis of a diallel cross in larch, in Fith World Forestry Congress, Seattle, Wa, August 29-September 10, 1960.

[22] Namkoong G., Introduction to quantitative genetics in forestry, U.S. Department of Agriculture, Forest Service, Technical Bulletin nr 1588, Washington D.C., 1979.

[23] Nanson A., Sacré E., A propos de l'hétérosis de Larix $\times$ eurolepis, en particulier pour les propriétés du bois, Bull. Rech. Agron. Gembloux, 13 (1978) 323-336.

[24] Nkongolo K.K., Klimaszewska K., Cytological and molecular relationships between Larix decidua, L. leptolepis and Larix $\times$ eurolepis: identification of species-specific chromosoms and synchronisation of mitotic cells, Theor. Appl. Genet. 90 (1995) 827-834.

[25] Pâques L.E., A critical review of larch hybridization and its incidence on breeding strategies, Ann. Sci. For. 46 (1989) 141-153.

[26] Pâques L.E., First evaluation of genetic parameters in a factorial mating design with hybrid larch (Larix decidua $\times$ Larix kaempferi), in: Proc. 'Results and future trends in larch breeding on the basis of provenance research' IUFRO Working Party S2.02-07, Berlin, 1992, pp. 136-145.

[27] Pâques L.E., I. Variabilité naturelle du mélèze, Mélèze d'Europe: bilan de 34 ans de test comparatif de provenances, Ann. Sci. For. 53 (1996) 51-67.

[28] Pâques L.E., II. Variabilité naturelle du mélèze, Mélèze du Japon: bilan de 36 ans de test comparatif de provenances, Ann. Sci. For. 53 (1996) 69-78.

[29] Pâques L.E., Interspecific hybridisation in larch: the long way to get outstanding varieties, in: Dungey H.S., Dieters M.J., Nikles D.G. (Compilers), Hybrid Breeding and Genetics of Forest Trees, Proc. of QFRI/CRC-SPF Symposium, 9-14 April 2000, Noosa, Queensland, Australia, pp. 373-385.

[30] Pâques L.E., Un programme d'amélioration ambitieux, in: Le mélèze, IDF, Paris, 2001.

[31] Qian T., Ennos R.A., Helgason T., Genetic relationships among larch species based on analysis of restriction fragment variation for chloroplast DNA, Can. J. For. Res. 25 (1995) 1197-1202.

[32] Samuel C.J.A., The estimation of genetic parameters for growth and stem form over 15 years in a diallel cross of Sitka spruce, Silvae Genet. 40 (1991) 67-72.

[33] Schneck V., Langner W., A long term breeding program of hybrid larch (Larix $\times$ eurolepis Henry), in: Dungey H.S., Dieters M.J., Nikles D.G. (Compilers), Hybrid Breeding and Genetics of Forest Trees, Proc. of QFRI/CRC-SPF Symposium, 9-14 April 2000, Noosa, Queensland, Australia, pp. 75-80.

[34] Schober R., Neue Ergebnisse des II, Internationalen Lärchenprovenienzversuches von 1958/59 nach Aufnahmen von Teilversuchen in 11 europäischen Ländern und den USA. Schriften aus der Forstlichen Fakultät der Universität Göttingen, Band 83, 1985, 164 p.

[35] Schober R., Rau H.M., Ergebnisse des I, Internationalen Japanlärchen-Provenienzversuches, Schriften aus der Forstlichen Fakultät der Universität Göttingen, Band 102, 1991, 168 p.

[36] Semerikov V.L., Lascoux M., Genetic relationship among eurasian and american Larix species based on allozymes, Heredity 83 (1999) $62-70$.

[37] Shelbourne C.J.A., Some insights on hybrids in forest tree improvement, in: Dungey H.S., Dieters M.J., Nikles D.G. (Compilers), Hybrid Breeding and Genetics of Forest Trees, Proc. of QFRI/CRCSPF Symposium, 9-14 April 2000, Noosa, Queensland, Australia, pp. 53-62.

[38] Sindelar J., Nektere Vysledky overovani vyberovych stromu modrinu opadaveho (Larix decidua Mill.) potomstvy z kontrolovaneho krizeni, Lesnictvi, 32 (1986) 1047-1068.

[39] Sindelar J., Genetics and improvement of European larch (Larix decidua Mill.), Annales forestales, Zagreb, 1992, 18/1, pp. 1-36.

[40] Sindelar J., Frydl J., Nektere geenticke parametry modrinu opadaveho (Larix decidua Mill.) na zaklade hodnoceni potomstev z dialelniho krizeni, Prace VULHM 79 (1994) 7-23.

[41] Stettler R.F., Zsuffa L., Wu R., The role of hybridization in the genetic manipulation of Populus, In Biology of Populus, Stettler, Bradshaw, Heilman, Hinckley, NRC-Research Press, Ottawa, 1996.

[42] Sylvestre-Guinot G., Pâques L.E., Delatour C., Résistance du mélèze hybride inoculé par Lachnellulla willkommii, Ann. For. Sci. 56 (1999) 485-492.

[43] Thill A., Palm R., Étude dendrométrique des mélèzes, Notes techniques du Centre d'Écologie forestière et rurale, $n^{\circ}$ 47, Fac. Sciences Agronomiques de Gembloux, 1984, 44 p. 